\title{
Postmodernism and the Church: An Opportunity and a Challenge
}

\begin{abstract}
Postmodernism is, in many respects, a term that has lost most of its cultural and academic cachet. This does not, however, mean that the themes, context, and conditions to which it referred are no longer relevant. In this essay, I will briefly review the latest reports which show a decreasing interest in organized religion, and interpret these results as symptomatic of a larger change in the state of knowledge. To this end, I will examine Jean-François Lyotard's analysis of the loss of metanarratives as a way of understanding the implicit rules of the dialogue that occurs between the theist and the atheist or agnostic. Next, I will note the unique capacity of beauty to transcend the diverse language games played by both sides of the conversation. I will conclude by contending that this characteristic of beauty offers a kind of common ground which can be built upon, fostering further dialogue as well as an opportunity for evangelization.
\end{abstract}

\section{Keywords}

Postmodernism, Lyotard, beauty, new evangelization, metanarratives, knowledge.

\section{Introduction}

In 2012, the Pew Research Center released a report finding that, "the number of Americans who do not identify with any religion continues to grow at a rapid pace.... In the last five years alone [for example], the unaffiliated have 
increased from just over $15 \%$ to just under $20 \%$ of all U.S. adults". ${ }^{1}$ More recent numbers from a May 12th, 2015 study demonstrate an even greater increase with nearly $23 \%$ of the U.S. adult population self-identifying as "nones" (i.e. no religious affiliation). ${ }^{2}$ This same study also shows that these numbers increase generationally, with the unaffiliated ranging from a mere $7 \%$ of the silent generation to an astonishing 35\% of millenials. The reasons for such a decline remain uncertain, though one report cites such possible explanations as political backlash, delays in marriage, broad social disengagement, and secularization. ${ }^{3}$ Whatever the cause, one thing remains clear: there are increasing numbers of people who see little or no relevance in associating themselves with a particular organized religion.

It is not surprising, therefore, that in the last few years U.S. Catholic Bishops have more frequently referred to the United States as mission territory, meaning that there are scores of men and women who have never heard the Gospel or who have formed false impressions of the Good News. ${ }^{4}$ While in itself this is an interesting development, the redefinition of a once thoroughly Christian nation as potentially fertile grounds for evangelization is not without precedent. At the very least, it can be traced back to Pope Saint John Paul II's 1990 encyclical letter Redemptoris Missio, where he writes that there exists a situation, "particularly in countries with ancient Christian roots, and occasionally in the younger Churches as well, where entire groups of the baptized have lost a living sense of the faith, or even no longer consider themselves members of the Church, and live a life far removed from Christ and his Gospel. In this case what is needed is a 'new

${ }^{1}$ C. Funk, G. Smith, „Nones” on the Rise: One-in-Five Adults Have No Religious Affiliation, (2012), p. 9. Pew Research Center, http://www.pewforum.org/2012/10/09/nones-on-the-rise (09.01.2016).

${ }^{2}$ G. Smith, America's Changing Religious Landscape: Christians Decline Sharply as Share of Population; Unaffiliated and Other Faiths Continue to Grow, Washington, D.C. 2015, p. 3.

${ }^{3}$ Funk and Smith, „Nones” on the Rise: One-in-Five Adults Have No Religious Affiliation, p. 29.

${ }^{4}$ See Catholic News Agency, Cardinal Dolan Sees US as „Mission Territory”, (2012), http:// www.catholicnewsagency.com/news/cardinal-dolan-sees-us-as-mission-territory (01.09.2016); Carl E. Olson, Abp. Chaput: „America Is Mission Territory - Whether We Recognize It yet or Not...”, (2013), http://www.catholicworldreport.com/Blog/2214/abp_chaput_america_is_ mission_territorywhether_we_recognize_it_yet_or_not.aspx (01.09.2016); A. Mena, Prayer Breakfast Speakers: US Church Called to Missionary Role, (2014), http://www.catholicnewsagency. $\mathrm{com} /$ news/prayer-breakfast-speakers-us-church-called-to-missionary-role (01.09.2016). 
evangelization' or a 're-evangelization"'.5 Accordingly, such a "re-evangelization" must necessarily take into account the changing social context and cultural conditions that have led to this loss of faith.

In this essay, I will attempt to identify those characteristics of the current situation which present both an opportunity as well as a challenge to the socalled "new evangelization". I will begin with a brief sketch of postmodernism against the foil of modernism, drawing out the important differences between the two in terms of their respective emphases, or lack thereof, on boundaries and definitions. I will then examine the crisis of knowledge, as understood by Jean-François Lyotard, specifically focusing on his problematic concerning the legitimation of knowledge. From there, I will examine how the new evangelization may stand to benefit from the postmodern condition as well as some of the additional challenges it will need to confront. I will then conclude with a brief examination of beauty as a particular form of knowledge that transcends the rigid rationality of the modern project and offers an invitation to dialogue with the Church.

\section{The Shift from Modernity to Postmodernism}

Postmodernism is a tricky term. Though the word itself has roots in the late 19th and early 20th century in Latin America, it was not until the 1980s and 1990s that the term really accumulated its cultural and philosophical cache. ${ }^{6}$ Even today, more than thirty years later, it still remains a bit obscure and vague. Some have connected it with various movements in philosophy (deconstructionism, post-structuralism, nonfoundationalism, language games, etc. $)^{7}$ and

${ }^{5}$ John Paul II, Encyclical Letter Redemptoris Missio of the Supreme Pontiff John Paul II, Washington, D.C. 1990, p. 30.

${ }^{6}$ See P. Anderson, The Origins of Postmodernity, London 1998, p. 3-6; J.-F. Lyotard, The Postmodern Condition: A Report on Knowledge, trans. Geoff Bennington and Brian Massumi, Minneapolis, 1984; G. Aylesworth, Postmodernism, ed. E. N. Zalta, The Stanford Encyclopedia of Philosophy (2015), http://plato.stanford.edu/archives/spr2015/entries/postmodernism (01.09.2016).

7 See Philipp W. Rosemann, Postmodernism, in New Catholic Encyclopedia Supplement 2012-2013: Ethics and Philosophy, ed. Robert L. Fastiggi, Detroit 2013.; Aylesworth, Postmodernism.; J.-F. Lyotard, The Postmodern Condition: A Report on Knowledge.; Brian C. Macallan and Jurgens Hendriks, Postfoundationalist Reflections in Practical Theology: A Framework 
aesthetics; ${ }^{8}$ others see it as an attitude towards life or a way of thinking about ourselves historically. ${ }^{9}$ Concerning its elusive nature, one author writes, "that postmodernism is indefinable is a truism. However, it can be described as a set of critical, strategic and rhetorical practices employing concepts such as difference, repetition, the trace, the simulacrum, and hyperreality to destabilize other concepts such as presence, identity, historical progress, epistemic certainty, and the univocity of meaning". ${ }^{10}$

Still others see "a new emphasis ... evident on deconstructing boundaries within and among different disciplines in the postmodern turn". ${ }^{11}$ However, even these boundaries and definitions are fluid and subject to revision, though not surprisingly, as change and the blurring of boundaries are core constituents of the postmodern mindset. Best and Kellner summarize these characteristics nicely: "There is today an emerging postmodern paradigm organized around a family of concepts, shared methodological assumptions, and a general sensibility that attack modern methods and concepts as overly totalizing and reductionistic; that decry utopian and humanistic values as dystopian and dehumanizing; that abandon mechanical and deterministic schemes in favor of new principles of chaos, contingency, spontaneity, and organism; that challenge all beliefs in foundations, absolutes, truth, and objectivity, often to embrace a radical skepticism, relativism, and nihilism; and that subvert boundaries of all kinds". ${ }^{12}$ Thus, to use Nietzsche's analogy borrowed from Greek mythology, one might say that modernity epitomizes the Apollonian - the rational, the harmonious, the

for a Discipline in Flux, Eugene 2014, p. 34.; B. Agger, Critical Theory, Poststructuralism, Postmodernism: Their Sociological Relevance, "Annual Review of Sociology" vol. 17 (1991), p. 111-12.

${ }^{8}$ See T. Hardy, Art Education in a Postmodern World Collected Essays, Bristol 2006, p. 7-11.; S. Best and D. Kellner, The Postmodern Turn, Critical Perspectives, New York 1997, p. 180.

9 See Umberto Eco, Postscript to the Name of the Rose, trans. William Weaver, San Diego 1984, p. 66-67. Especially the following: "I think of the postmodern attitude as that of a man who loves a very cultivated woman and knows that he cannot say to her „I love you madly", because he knows that she knows (and that she knows he knows) that these words have already been written by Barbara Cartland. Still there is a solution. He can say „As Barbara Cartland would put it, I love you madly”. At this point, having avoided false innocence, having said clearly it is no longer possible to talk innocently, he will nevertheless say what he wanted to say to the woman: that he loves her in an age of lost innocence."

${ }^{10}$ G. Aylesworth, Postmodernism.

11 S. Best and D. Kellner, The Postmodern Turn, p. 258.

12 S. Best and D. Kellner, The Postmodern Turn, p. 19. 
congruent, the ordered - while postmodernity represents the Dionysian - the irrational, the chaotic, the spontaneous, the incongruent.

Accordingly, if postmodernism can be described as the elimination of borders and demarcation, then modernity and modernism can be seen as an emphasis on definition of boundaries and categories. Turning to modern philosophy, this is precisely what one finds in Descartes' Meditations in his pursuit of "clear and distinct knowledge". ${ }^{13}$ A century later, this is confirmed once again in Kant's Critique of Pure Reason, aimed at discovering the limits of knowledge. In politics and society, this same rationalist approach can be seen in the values of the enlightenment thinkers, emphasizing universals and rights (e.g. Locke and Rousseau, even if they may have differed on some key points). This same focus can be found once again in the first and second industrial revolution, in both the scientific attitude taken towards experimentation and nature as well as man's relationship to labor and work. ${ }^{14}$ Ford's assembly line process presents a particularly paradigmatic example of this in which each worker is reduced to performing a very specific function, dividing and compartmentalizing the skills necessary to produce an automobile in order to increase efficiency.

In the twentieth century, philosophically and culturally things begin to change. After the First World War, the optimism associated with modern progress in the sciences and industry begins to crumble. William Barrett comments: "The period from 1870 to 1914 has been aptly described by one historian as the generation of materialism: the principle countries of Europe had become unified as nations, prosperity was in the air, and the bourgeois contemplated with self-satisfaction an epoch of vast material progress and political stability. August 1914 shattered the foundations of that human world. It revealed that the apparent stability, security, and material progress of society had rested, like everything human, upon the void. European man ... saw that his rational and enlightened philosophy could no longer console him with the assurance that it satisfactorily answered the question What is man? [Correspondingly,] existential philosophy (like much of modern art) is thus a product of bourgeois society in

13 R. A. Watson, Rene Descartes, (2015), http://www.britannica.com/biography/ReneDescartes (1.9.2015).

${ }^{14}$ In an effort to make this essay more readable, all nouns of undefined gender will be referenced using masculine pronouns. In addition, rather than using such awkward terms as humankind, the inclusive "man" or "men" will be used. In all cases these terms should be understood to include both men and women. 
a state of dissolution". ${ }^{15}$ Indeed, Jean-Paul Sartre's quintessential existentialist work Being and Nothingness was published in 1943 at a time when France, and Europe in particular, among the nations of the world, was experiencing a heightened state of crisis.

If it was difficult then to maintain a utopian confidence in the progress of modernity after the First World War, it was even more so towards the end of the second. Though arguably not the first existentialist writer, Sartre marked something of a change in philosophy and, along with Camus, existentialist ideas and themes achieved a level of international fame and significance. It is not difficult to imagine that this was, in no small part, due to the effects of the wars of the first half of the twentieth century, which witnessed the more insidious side of the advances in technology. Correspondingly, in the generations that followed, it became more difficult to maintain the same optimistic narrative that so captured many generations before. For those born in the immediate aftermath of the Second World War, viz. the baby-boomers, the world would be seen as a both full of wonder as well as danger, with the progress posed by the modern project of a decidedly dual nature. That is, though it may bring about much good (e.g. medicine, higher standards of living, greater comfort, etc.), it might also produce such evils as the world had never before seen (e.g. the scientific experiments of Auschwitz or the destructive capacity of the nuclear bomb).

As this same generation came of age in the 1960s, the world was an increasingly uncertain place. In the U.S., men and women lived under the possibility of a nuclear attack by the Soviet Union, with the Cuban Missile Crisis in 1962 providing a particular example of just how tenuous the situation was. 1963 saw the Birmingham Riot and the Kennedy assassination, while a year later, the riots continued in the wake of the Civil Rights Act of 1964. In 1960, France detonated its first atomic bomb, and 1961 saw the building of the Berlin Wall in Germany. Around the same time, Pope Saint John XXIII called the Second Vatican Council which met for the first time in 1962 with potentially (and now we can say definitively) sweeping changes for the Catholic Church. The '60s also saw Che Guevara making his way through South America in an effort to spread revolution. Meanwhile, Africa saw major decolonization in which 32 countries achieved independence in just 8 years.

In their book The Postmodern Turn, Best and Kellner note that these and many more significant world events were the social context in which "most of the

15 W. Barrett, Irrational Man : A Study in Existential Philosophy, New York 1990, p. 35. 
major postmodern theorists - Foucault, Lyotard, Baudrillard, Deleuze, Guattari, Jameson, Laclau, Mouffe, Harvey and others - participated in, and were deeply influenced by" ${ }^{16}$ At the same time, "thinkers like Foucault, Derrida, Lyotard, and Deleuze were turning to Nietzsche and Heidegger and appropriating their critical discourses against modern theory and modernity itself. Postmodern assaults on Enlightenment rationality and universalism, as well as postmodern emphases on relativism, perspectivalism, difference, and particularity, stem as much from philosophical critiques of Western thought that begin with Nietzsche and continue through Dewey, Wittgenstein, Heidegger, and feminism, as from particular political experiences". ${ }^{17}$ In the decades that followed 1960s, modernity and the inevitable march of progress were increasingly seen as empty promises. During this time (and indeed before), there was a cultural, intellectual, and philosophical shift away from absolute foundations and principles. Nevertheless, it is important to point out that such a "turn" or "shift" does not necessarily represent a rupture with the past. Instead, it may be seen as a change of emphasis or a heightening of the latent and possibly contradictory traits that have been present alongside modernity itself. ${ }^{18}$ This shift, therefore, does not necessarily signify a break with modernity, but, perhaps instead, a confrontation between elements within the modern project itself. In this way, Best and Kellner can

16 S. Best and D. Kellner, The Postmodern Turn, p. 5.

17 S. Best and D. Kellner, The Postmodern Turn, p. 6.

18 S. Best and D. Kellner, The Postmodern Turn, p. 25. They write, "Extreme postmodernists should be distinguished from those who use a more qualified and modest mode of the postmodern discourse, who do not advocate a fundamental break either with modernity or with modern theory. The more moderate versions put their emphasis on the modern and interpret the postmodern merely as a mutation of the modern, as a shift within modernity. Moderate postmodern theorists like Lyotard (sometimes), Foucault, Laclau, Mouffe, Harvey, Rorty, and others combine modern and postmodern discourses and interpret the postmodern primarily as a modality of the modern rather than as its radical other. ... Indeed, we choose to deploy the discourse of a postmodern 'turn' or 'shift' instead of 'rupture' which stresses extreme breaks, discontinuities, and an apocalyptic sense of ending and completely new beginnings. Rather, for us the notions of 'shift' and 'turn' signify novel developments, yet also retain continuities with modernity and modern theory, pointing to shared assumptions, presuppositions, modes of thought and discourse, practices and strategies, and vision. Seeing the postmodern as continuous with the modern eschews postulating a radical rupture in theory and history. ... Likewise, taking postmodern theory as continuous with and supplementary to modern theory interprets postmodern discourse as an intensification of critical tendencies of such modern figures as Nietzsche, Heidegger, or Dewey rather than as a leap into whole new mode of discourse altogether." 
refer back to someone like Nietzsche or John Dewey and see the seeds of postmodernism in their nascent form.

In the late 1970s, in an attempt to make sense of these changing currents and shifts in thought, the Conseil des Universités in Quebec commissioned JeanFrançois Lyotard to present a report on "the condition of knowledge in the most highly developed societies". ${ }^{19}$ In it, he uses "the word postmodern to describe the condition, a word in current use on the American continent among sociologists and critics, that designates the state of our culture following the transformations which, since the end of the nineteenth century, have altered the game rules for science, literature, and the arts". ${ }^{20}$ Thus, insofar as these transformations are critical to understanding the postmodern context, the following section will be devoted to their explanation, specifically the crisis of knowledge, narrative, and language games, insofar as they reflect the changing status of knowledge and a corresponding decline in confidence in the modern project.

\section{Narratives and the Crisis of Knowledge}

Lyotard's aim in The Postmodern Condition is to describe the changing status of, what he refers to as, 'metanarratives' in an attempt to make sense of the trends in science and technology and their corresponding effect on society and culture. What he finds in his investigation is a process of delegitimization inherent within the modern project that leads to a crisis of knowledge which, in the pursuit of its own legitimation must recognize certain unstable foundations. Building upon Wittgenstein's concept of language games, Lyotard notes that "science has always been in conflict with narratives". Before diving into his analysis of the problem however, it will help to first briefly review his presentation of the process of legitimation which he believes has traditionally relied upon narratives and metanarratives.

For Lyotard, the problem of legitimation is intimately tied to the question of knowledge, or, in other words, the definition of knowledge. Modern science has its various methods, qualifications and protocols to determine what constitutes scientific knowledge. Any information or data that falls outside these bounds cannot therefore be considered knowledge, at least not scientifically speaking.

19 J.-F. Lyotard, The Postmodern Condition: A Report on Knowledge, p. xxiii.

${ }^{20}$ J.-F. Lyotard, The Postmodern Condition: A Report on Knowledge, p. xxiii. 
Yet the question of what constitutes knowledge is not confined merely to the sciences however. In everyday circumstances, knowledge is much more widely defined. Appropriately, Lyotard comments that: "What is meant by the term knowledge is not only a set of denotative statements, far from it. It also includes notions of 'know-how', 'knowing how to live,' 'how to listen,' etc. Knowledge, then, is a question of competence that goes beyond the simple determination and application of the criterion of truth, extending to the determination and application of criteria of efficiency (technical qualification), of justice and/or happiness (ethical wisdom), of the beauty of a sound or color (auditory and visual sensibility), etc." ${ }^{21}$ This question, therefore, is not simply one of determining qualifying criteria, but also how one lives and how one may validate these forms of knowing.

Traditionally, many common forms of validated knowledge come through the transmission of narratives. In this sense, the authority of the person telling the narrative is intimately involved with the information or knowledge that is transmitted from one person to another. Often, this happens in the form of telling stories that explain certain events or relationships to one's society and the world. In a Judeo-Christian context the most obvious example can be seen in some of the stories of the bible. The book of Genesis, for example, provides an explanation for the fallen state of man and his inclination to sin through the retelling of the story of Adam and Eve. Unlike scientific knowledge, this form of narrative does not require definite and distinct criteria by which one judges the validity of the story. Rather it is self-validating as a consequence of the context and the way in which it is told. Genesis begins, for example, with the words, "in the beginning", signifying an ancient account to which the teller of the story makes no claim to have created, but rather to have received. The Gospel of John takes up this same form, starting once again with the words "in the beginning" which convey to the listener a sense of authority which surpasses whatever more immediate authority the storyteller may command. In this sense, the authority of the narrator is more aptly understood as the authority of the story.

Lyotard refers to this form of validation as the "pragmatics of transmission" which necessarily involve some formulaic such as "in the beginning" that mark the account as transcending the storyteller himself. Thus, for Lyotard, "the narrator's only claim to competence for telling the story is the fact that he has heard it himself. The current narratee gains potential access to the same authority

${ }^{21}$ J.-F. Lyotard, The Postmodern Condition: A Report on Knowledge, p. 18. 
simply by listening. It is claimed that the narrative is a faithful transmission (even if the narrative performance is highly inventive) and that it has been told 'forever"' ${ }^{22}$ Correspondingly, the narrator's only claim to authority in telling the story is the story itself as handed down by oral tradition. This story then makes its own claim to authenticity by virtue of its being told from generation to generation. Yet the words themselves may form only a part of the "pragmatics of transmission". Ritual, ceremony, signs and symbols also lend to the authority of the message transmitted.

Nevertheless, ultimately "what is transmitted through these narratives is the set of pragmatic rules that constitutes the social bond" ${ }^{23}$ This is what constitutes the true strength of the narrative form insomuch as it legitimates the way of life, culture, or society in which it is told. "Narratives," according to Lyotard, "determine criteria of competence and/or illustrate how they are to be applied. They thus define what has the right to be said and done in the culture in question, and since they are themselves a part of that culture, they are legitimated by the simple fact that they do what they do". ${ }^{24}$

Consequently, questions concerning the validity of knowledge are not a problem because the narratives form an integral part of the society, sustaining and supporting the institutions and actions of the community. The foundations for the expression of culture are thus intimately woven into the fabric of the lives of the people because the narrative forms a part of who they are, while they themselves constitute part of the narrative through the telling and retelling of the self-legitimating story.

According to Lyotard, there are two such narratives which legitimated the modern project and lent a cohesive sense of meaning to society and culture: the hero of liberty and the hero of knowledge respectively. ${ }^{25}$ The former emphasizes the rights of man to liberty and science and aims to overthrow those institutions and traditions that prevent man from realizing these ends. The French Revolution represents an exemplar of the spirit of this narrative. The Declaration of Independence of the United States of America offers another, especially with respect to the pride of place given to life, liberty and the pursuit

\footnotetext{
22 J.-F. Lyotard, The Postmodern Condition: A Report on Knowledge, p. 20.

23 J.-F. Lyotard, The Postmodern Condition: A Report on Knowledge, p. 21.

24 J.-F. Lyotard, The Postmodern Condition: A Report on Knowledge, p. 23.

25 J.-F. Lyotard, The Postmodern Condition: A Report on Knowledge, p. 31.
} 
of happiness. In contrast to the first narrative, the second emphasizes the philosophical over the political (though they are present in both). This is best embodied in the philosophies of Fitche, Schelling, and Hegel and German idealism. It is the speculative spirit and, as Lyotard puts it, "the mechanism of developing a Life that is simultaneously Subject, that we see a return of narrative knowledge. There is a universal 'history' of spirit, spirit is 'life,' and 'life' is its own self-presentation and formulation in the ordered knowledge of all its forms contained in the empirical sciences. ... [It is] in the names 'Life' and 'Spirit' [that] knowledge names itself". ${ }^{26}$ This can be seen best in Hegel's Lectures on the Philosophy of History especially with regard to the spirit unfolding through history and the people as well as its activity to promote those changes.

However, in the first half of the twentieth century, Lyotard begins to identify changes to the status of these narratives in Western culture and society. He notes that, "in contemporary society and culture - postindustrial society, postmodern culture - the question of the legitimation of knowledge is formulated in different terms. The grand narrative has lost its credibility, regardless of what mode of unification it uses, regardless of whether it is a speculative narrative [the hero of knowledge] or a narrative of emancipation [the hero of liberty]. The decline of narratives can be seen as an effect of the blossoming of techniques and technologies since the Second World War, which has shifted emphasis from ends of action to its means". ${ }^{27}$ Nevertheless, this is not due to any external factors which might have dethroned these narratives, but rather a result of contradiction and tension within the narratives themselves. Unlike the selfvalidating narratives that have the power to unify a culture and a society through the reciprocal validation of the story and the people, the criteria that justify scientific knowledge cannot ground science itself. Rather, science provides access to knowledge through its own process of legitimation (i.e. the scientific method) and, consequently, this knowledge is "true" because it conforms to the appropriate criteria. However, though one can claim, as Lyotard writes, that "What I say is true because I prove that it is... what proof is there that my proof is true?". ${ }^{28}$ Proving the validity of science requires an explanation beyond the scientific method which itself can only determine what qualifies as true scientific knowledge.

26 J.-F. Lyotard, The Postmodern Condition: A Report on Knowledge, p. 34-35.

27 J.-F. Lyotard, The Postmodern Condition: A Report on Knowledge, p. 37.

28 J.-F. Lyotard, The Postmodern Condition: A Report on Knowledge, p. 24. 
Science, then, can provide only a limited, narrow explanation for those certain types of lived experience that fall within the bounds of the experiment. Lyotard uses Wittgenstein's concept of language games to help make this clear, explaining that each process of legitimation defines specific rules which either include or exclude certain types of knowledge. In this way, the set of rules for the language game of science differ from those of ethics, aesthetics, politics, etc. This means that what qualifies as knowledge in one game may not necessarily satisfy the rules for another. The same may be said with regard to the difference between narrative knowledge and scientific knowledge. Lyotard continues, acknowledging that "it is therefore impossible to judge the existence or validity of narrative knowledge on the basis of scientific knowledge and vice versa: the relevant criteria are different. ... [As a result,] lamenting the 'loss of meaning' in postmodernity boils down to mourning the fact that knowledge is no longer principally narrative". ${ }^{29}$

Thus, one of the principle functions performed by the narrative escapes the language game of science, specifically that of ratifying those social and cultural bonds that unify a people. ${ }^{30}$ This is because science cannot legitimate the knowledge of "know-how," "knowing how to live," "how to listen," aesthetics, ethics, etc. The grand narratives that may have once provided a cohesive explanation that included these other types of knowledge no longer hold. "There is, then", Lyotard writes, "an incommensurability between popular narrative pragmatics, which provides immediate legitimation, and the language game known to the West as the question of legitimacy - or rather, legitimacy as a referent in the game of inquiry." ${ }^{11}$ The increasing reliance on science as the source of "true" knowledge combined with the decline of the grand narratives leads therefore to a particular crisis of knowledge, itself the result of science's inability to self-validate and subsequently provide a firm cultural and social foundation.

Indeed, without the grand narrative, the question of legitimation affects all language games equally. The initial hegemony enjoyed by science crumbles in the very attempt at self-validation. Consequently, Lyotard can write that, "what we have here is a process of delegitimization fueled by the demand for legitimation itself. The 'crisis' of scientific knowledge, signs of which have been accumulating

\footnotetext{
29 J.-F. Lyotard, The Postmodern Condition: A Report on Knowledge, p. 26.

30 J.-F. Lyotard, The Postmodern Condition: A Report on Knowledge, p. 25.

31 J.-F. Lyotard, The Postmodern Condition: A Report on Knowledge, p. 23.
} 
since the end of the nineteenth century, is not born of a chance proliferation of sciences... It represents, rather, an internal erosion of the legitimacy principle of knowledge. There is erosion at work inside the speculative game, and by loosening the weave of the encyclopedic net in which each science was to find its place, it eventually sets them free. The classical dividing lines between the various fields of science are thus called into question - disciplines disappear, overlappings occur at the borders between sciences, and from these new territories are born". ${ }^{32}$

This, then, is exactly the situation that was described at the beginning of the previous section which defined the postmodern condition as precisely one in which boundaries and limits break down, allowing the content from one discipline to flow into another and vice-versa. Because science fails to legitimate itself from within its own language game and because there exists no grand narrative which might legitimate it from without, the game of science can claim no authority over any other game. "The game of science is thus put on par with the others" ${ }^{33}$

This apparent "demotion" is not unique to science however. Rather the loss of the grand narrative affects all other disciplines to the extent to which no one language game (i.e. discipline) can claim supremacy over any other. What makes this particularly important with regard to the game of science however, is the special pride of place it was afforded insofar as it formed an integral part of the rationalist foundation that provided the basis for the modern emphasis on progress towards the culmination of man. The dissolution of grand narratives along with the deposition of science thus paved the way for a major loss of confidence in the foundation of modernity and those societies that were built upon it. This uncertainty and lack of confidence finds its most apt expression in the tumultuous decade of the ' 60 s which, as was discussed earlier, represents something of a turning point - viz. the postmodern turn - in the modern project.

\section{The Challenge and the Opportunity}

Shifting back to the question of the Catholic Church and its mission, this postmodern turn represents both something of a challenge as well as an opportunity. On the one hand, there are some very real aspects of the post-

\footnotetext{
32 J.-F. Lyotard, The Postmodern Condition: A Report on Knowledge, p. 39.

33 J.-F. Lyotard, The Postmodern Condition: A Report on Knowledge, p. 40.
} 
modern condition that are simply antithetical to the philosophy, theology, and anthropology of the Church. On the other hand, other characteristics may present themselves as new avenues of evangelization that would not otherwise have been available in a purely modern context. Indeed, considering that the modern project itself was conceived at least in part with anti-traditional, and later on, anti-religious sentiment, and, insofar as postmodernism represents a shift away from such attitudes, it may be seen to offer new grounds for conversation and dialogue. At the same time, insomuch as postmodernism signifies a move away from foundational philosophy, it presents some serious difficulties for a religion that views reason as capable of grasping some basic truths about God and man. ${ }^{34}$

Correspondingly, the loss of grand narratives and the proliferation of language games without the supporting structure of foundational principles represents a real challenge to the mission of the Church which, in an effort to share the Gospel, seeks to affirm reason's basic capacity to know its Creator. ${ }^{35}$ The decline of confidence in reason's capacity to know truth with certainty stands out as a particular threat. Commenting on this, Pope Saint John Paul II writes in his encyclical Fides et Ratio that, "the currents of thought which claim to be postmodern merit appropriate attention. According to some of them, the time of certainties is irrevocably past, and the human being must now learn to live in a horizon of total absence of meaning, where everything is provisional and ephemeral. In their destructive critique of every certitude, several authors have failed to make crucial distinctions and have called into question the certitudes of faith. This nihilism has been justified in a sense by the terrible experience of evil which has marked our age [e.g. the wars of the 20th century]. Such a dramatic experience has ensured the collapse of rationalist optimism, which viewed history as the triumphant progress of reason, the source of all happiness and freedom; and now, at the end of this century, one of our greatest threats is the temptation to despair". ${ }^{36}$ Thus, relative truth as determined by the manifold criteria of individual language games naturally gives rise to a sense of skepticism concerning the existence of transcendental Truth. Indeed, questions concerning truth,

${ }^{34}$ See Catholic Church, Catechism of the Catholic Church, Washington, DC 1997, p. 39-41; John Paul II, Fides Et Ratio [Encyclical on the Relationship between Faith and Reason], Boston 1998.

35 John Paul II, Fides Et Ratio, $\$ 19$.

36 John Paul II, Fides Et Ratio, $\$ 91$. 
metaphysics, or first principles become seen as not only impossible to answer but meaningless in themselves, as emphasized by such philosophers as John Dewey, who writes that, "Old ideas give way slowly; for they are more than abstract logical forms and categories. ... Moreover, the conviction persists-though history shows it to be a hallucination - that all the questions that the human mind has asked are questions that can be answered in terms of the alternatives that the questions themselves present. But in fact intellectual progress usually occurs through sheer abandonment of questions together with both of the alternatives they assume - an abandonment that results from their decreasing vitality and a change of urgent interest. We do not solve them: we get over them. Old questions are solved by disappearing, evaporating, while new questions corresponding to the changed attitude of endeavor and preference take their place. Doubtless the greatest dissolvent in contemporary thought of old questions, the greatest precipitant of new methods, new intentions, new problems, is the one effected by the scientific revolution that found its climax in the Origin of Species". ${ }^{37}$

Consequently, one ought to focus on matters of pragmatic import instead of arguing about metaphysical realities which may admit of contradictory alternatives. As discussed earlier, this can be seen in the decline of narrative especially after the Second World War with shift of emphasis from the ends of action to its means. ${ }^{38}$

For the Church, this turn represents a serious problem insofar as it aims to deny man the epistemological capacity to know who he is and what his end ought to be. Even more concerning are the potential effects on ethics which, when disconnected from a teleologically oriented anthropology, become questions not about how man ought to act but rather, for example, how man ought to behave such that his actions negatively infringe as little as possible on the lives of others. ${ }^{39}$ With no first principles or certain knowledge to depend upon, man defaults to a basic philosophy of nihilism and, if one follows Dewey, pragmatism.

Nevertheless, for all the possible dangers and pitfalls that postmodernism represents, it also affords some opportunities that the modern project would

37 J. Dewey, The Middle Works of John Dewey, 1899-1924. Volume 4: 1907-1909, Essays, Moral Principles in Education, Charlottesville 2003, p. 15.

38 J.-F. Lyotard, The Postmodern Condition: A Report on Knowledge, p. 37.

39 A caveat: It should be noted that this is just one example of pragmatic system of ethic. Others may be constructed with other goals in mind. What they will all have in common will be their lack of recourse to a conception of the essence of man. 
otherwise reject. For example, unlike modernity, postmodernism does not take the same staunch anti-traditionalist approach towards religion, which may result in a certain openness or receptivity to tradition or religion as modes of engaging with one's reality. In fact, the reduction of science to simply one more language game among many makes it easier to see other disciplines and ways of life as significant in and of themselves. This is important because it opens up new horizons as possible sources of meaning and perhaps even to Truth itself which is made difficult or impossible in a society or culture that values the opinion of the expert scientist as the only valid form of knowing. A critique of this kind of cultural attitude can be found in an essay by HansGeorge Gadamer entitled The Limitations of the Expert, wherein he examines the way in which Western societies have increasingly placed all decision making authority in the hands of the expert to the detriment of the common man, relegating an individual's decisions to those who supposedly command the greatest knowledge in a particular field or discipline. ${ }^{40}$ This implicitly has the effect of questioning one's capacity to know per se without appeal to the presumed expert.

In contrast, recognizing the game of science as only one in a plurality of games allows the individual to appeal to other modes of knowing that otherwise may not fit nicely into the scientific method. This has the effect of opening up new, perhaps previously ignored or disdained, sources of knowledge, such as theology or aesthetics, that would have not been considered in different circumstances. For the person searching for answers to the great questions of life - e.g. "Why am I here?" or "What is my purpose?" - the Church becomes a place where these questions may find their answers. At the same time, (it) postmodernity opens up to the Church many new avenues of dialogue for new evangelization insofar as truth is no longer seen as the sole domain of the sciences or the expert, but is instead available to the common man or woman.

Likewise, the elimination of borders and boundaries between different domains can also make the average person amenable to the idea that truth may be found in many different, distinct places. Nature, philosophy, theology, aesthetics, language, culture, and tradition all become relevant insofar as they offer ways of interacting with the world and sources of knowledge. Aesthetics, perhaps in particular among the different domains, offers a unique encounter

${ }^{40}$ H. G. Gadamer, D. Misgeld, and G. Nicholson, Hans-Georg Gadamer on Education, Poetry, and History: Applied Hermeneutics, Albany 1992, p. 181. 
through the experience of beauty in which one comes face to face with a kind of knowledge that transcends the intellect. Pope Emeritus Benedict XVI comments on this noting that, "beauty is knowledge, indeed, a higher form of knowing, because it strikes man with the truth in all its greatness. ... [Cabasilas for example,] distinguishes two kinds of knowledge: one is knowing through instruction, which remains secondhand and does not put the knower in contact with reality itself. The second kind of knowledge, in contrast, is knowing through personal experience, through contact with the things themselves". ${ }^{41}$ This latter kind of knowledge strikes in an immediate way and, analogous to the narrative form, validates itself in the selfsame experience. It requires no external criteria but instead provides the standard by which one may evaluate not only future experiences but the arguments themselves.

Beauty becomes an encounter, which opens the conversation to the possibility of that which transcends the immediate, to something beyond mere syllogistic reasoning. Pope Benedict describes this experience vividly: "The encounter with beauty can become the wound of the arrow that strikes the soul and thus makes it see clearly, so that henceforth it has criteria, based on what it has experienced, and can now weigh the arguments correctly. For me an unforgettable experience was the Bach concert that Leonard Bernstein conducted in Munich after the sudden death of Karl Richter. I was sitting next to the Lutheran Bishop Hanselmann. After the last note of one of the great Thomas Kantor cantatas triumphantly faded away, we looked at each other spontaneously and just as spontaneously said: "Anyone who has heard this knows that the faith is true". Such an extraordinary force of present reality had become audible in this music that the audience knew, no longer through deduction, but by the impact that it could not have come from nothing; it could only have been born through the power of the truth that makes itself present in the composer's inspiration". ${ }^{42}$ It is this presence in the experience of beauty that arrests, questions, and declares. It is an event that overwhelms and compels one to reevaluate presumptions and prejudices. It becomes a moment of receptivity of an other, of a person, who cannot be reduced to facts or figures. For the Church, beauty becomes an invitation to dialogue grounded not on rigid rationalism but rather upon the experience of a presence that transcends quantity and calculation.

${ }^{41}$ Benedict XVI, On the Way to Jesus Christ, San Fransico 2005, p. 35-36. Pope Benedict quotes here from Nicholas Cabasilas, Life in Christ, the second book, p. 15.

42 Benedict XVI, On the Way to Jesus Christ, p. 37. 
In conclusion, postmodernism offers an opportunity for the Church and the new evangelization insofar as it represents a transition from the anti-traditional, anti-religious sentiments of the modern project. At the same time, it presents a challenge insofar as the decline of narrative and the proliferation of language games tends towards an implicit nihilism and relativism. Nevertheless, the destabilizing effect of postmodernism on the presuppositions of science and technology makes the postmodern man and woman more receptive to the possibility of the existence of knowledge beyond the scientific method and mere syllogistic reasoning. Finally, it presents an opening through which the Church may emphasize the role of beauty as an unmediated encounter with the truth that transcends the rational demands of the modern project.

\section{Bibliography}

Agger B., Critical Theory, Poststructuralism, Postmodernism: Their Sociological Relevance, „Annual Review of Sociology” vol 17 (1991), p. 105-31.

Anderson P., The Origins of Postmodernity, London 1998.

Aylesworth G., Postmodernism, ed. Edward N. Zalta, The Stanford Encyclopedia of Philosophy (2015), http://plato.stanford.edu/archives/spr2015/entries/postmodernism (1.9.2016).

Barrett W., Irrational Man: A Study in Existential Philosophy, New York 1990.

Benedict XVI, On the Way to Jesus Christ, San Fransico 2005.

Best S., and Kellner D., The Postmodern Turn, Critical Perspectives, New York 1997.

Catholic Church, Catechism of the Catholic Church, Washington, DC 1997.

Catholic News Agency, Cardinal Dolan Sees US as „Mission Territory”, (2012), http://www. catholicnewsagency.com/news/cardinal-dolan-sees-us-as-mission-territory (1.9.2016).

Dewey J., The Middle Works of John Dewey, 1899-1924. Volume 4: 1907-1909, Essays, Moral Principles in Education, Charlottesville, 2003.

Eco U., Postscript to the Name of the Rose, trans. William Weaver, San Diego 1984.

Funk C., and Smith, G., „Nones” on the Rise: One-in-Five Adults Have No Religious Affiliation, (2012).

Gadamer H.G., Misgeld, D., and Nicholson, G., Hans-Georg Gadamer on Education, Poetry, and History: Applied Hermeneutics, Albany 1992.

Hardy T., Art Education in a Postmodern World Collected Essays, Bristol 2006.

John Paul II, Encyclical Letter Redemptoris Missio of the Supreme Pontiff John Paul II, Washington, D.C. 1990. 
John Paul II, Fides Et Ratio [Encyclical on the Relationship between Faith and Reason], Boston, 1998.

Lyotard J., The Postmodern Condition: A Report on Knowledge, trans. Geoff Bennington and Brian Massumi, Minneapolis, 1984.

Macallan B., and Jurgens H., Postfoundationalist Reflections in Practical Theology: A Framework for a Discipline in Flux, Eugene 2014.

Mena A., Prayer Breakfast Speakers: US Church Called to Missionary Role, (2014), http:// www.catholicnewsagency.com/news/prayer-breakfast-speakers-us-church-calledto-missionary-role (1.9.2016).

Olson C., Abp. Chaput: „America Is Mission Territory-Whether We Recognize It yet or Not...”, (2013), http://www.catholicworldreport.com/Blog/2214/abp_chaput_ america_is_mission_territorywhether_we_recognize_it_yet_or_not.aspx (1.9.2016).

Rosemann P., Postmodernism, in New Catholic Encyclopedia Supplement 2012-2013: Ethics and Philosophy, ed. Robert L. Fastiggi, Detroit 2013.

Smith G., America's Changing Religious Landscape: Christians Decline Sharply as Share of Population; Unaffiliated and Other Faiths Continue to Grow, Washington, D.C. 2015.

Watson R., Rene Descartes, (2015), http://www.britannica.com/biography/Rene-Descartes (1.9.2015). 